\title{
The Influence of Job Satisfaction and Non Material Incentives on Employee Performance at Fave Hotel Jakarta, Indonesia
}

\author{
Grace Orlyn Sitompul \\ Universitas Advent Indonesia \\ grace.sitompul@unai.edu
}

\begin{abstract}
Employee attitudes are very significant to management and Organizations since today determine the behavior of employee in an Organization. It is believed that employees who are satisfied are normally productive than their counterparts who are dissatisfied. Although some researches focused on job satisfaction and employee performance, empirical work on the determinants of job satisfaction, non-material incentive and its effect on performance especially in hotel is scanty. The purpose of this study was to analyze the effects of job satisfaction and non material incentive among the workforce of Fave Hotel Jakarta on employee performance. Data collections used in this study is by distributing questionnaires. The method used in this research was descriptive method, and the data obtained were processed statistically using multiple linear regression analysis, and also uses primary data. The sample of the study is comprised of 61, Human Resources, Finance, House Keeping, Food \& Beverages, Sales \& Marketing, Front Office, Engineer, and Security Department in Fave Hotel, Jakarta. 61 Questionnaires were distributed out of which 30 were received back and used for analysis. SPSS is used for data analysis statistically. Based on the first results shown that the correlation coefficient $\mathrm{r}=0.503$, with $0.005<0.05$ which means there were significant influence between job satisfaction on employee performance. Second result found the correlation coefficient $\mathrm{r}=0.031$, with $0.870>0.05$ which means there were no significance influence between non material incentives on employee performance, hence $\mathrm{Ha}$ declined and Ho accepted. Simultaneously result showed that the correlation coefficient $r=$ 0.511 , with $\mathrm{f}$ sig $0.017<0.05$, which means there were significance influence between job satisfaction and non material incentives on employee performance. Result suggested the facets such as: pay, promotion, relationship with co-workers and supervisor support the organization and for further research can add other independent variables with motivation, individual characteristics and organizational setting be particularly important determinant of employee performance.
\end{abstract}

Keywords: Job Satisfaction, Non-Material Incentives, Employee Performance.

\section{INTRODUCTION}


In the era of globalization many companies compete to become a superior company for the sake of earning much profit. To meet these targets, good management is needed in order to manage each of its activities. Good management is management that gives special attention to employees who work on it. Employees are resources and aspects that are very important to achieve the company goals. Thus employee's performance is very influential for company productivity.

In fact, many companies ignore the aspect of human resources they have and focus on company profit only. Thus, employee must be treated as company assets that must be properly guarded and treated accordingly. Meanwhile, the management needs to provide a positive impetus for each employee, because employees are not machines that can work continuously without stopping. Therefore, employees should be hired humanely without ignoring their needs at work. In addition, according to researchers' observations, other problems that often occur in companies related to employee are the lack of employee performance in carrying out their duties and the functions in the company. This is seen from the lack of innovation from employees so they feel bored with their work and prefer to stop working or find another job. In addition the company also provides warnings or penalties in accordance with company policy for employees who have not been maximized at work or did not reach the assessment target, such as less contribution to the company goals, lack discipline in running the rules and regulations, and often late come to the office.

Many ways can be done by management to achieve company goals, one of which is through employee job satisfaction and providing non-material incentives as an award for them. Whether good or not are the company, it depends on each individual who is working on it, including job satisfaction for each employee. In connection with this, in order to strive for the realization of employee job satisfaction, then the company must provide a conducive working environment. According to Atmosoeprapto in Nasution (2015) stated that the business environment will determine the success of an organization. Further, according to Gunlu in Taurisa and Ratnawati (2012) explained that job satisfaction has a significant effect on organizational commitment that can improve an employee's performance. Thus, it can be assumed that the level of employee job satisfaction is directly proportional to the level of employee performance.

Then to support the performance of employees one of which can be supported through the provision of non material incentives. As for the purpose of human work is to meet all their needs by working, therefore people expect remuneration provided in accordance with the 
work done to improve their work performance. Mangkunegara (2009) stated that "employee performance is the result of quality and quantity of work achieved by an employee in carrying out their duties in accordance with the responsibilities given to them" (p. 67). With the great influence of human resources for the company, employee should pay more attention through policies. One of the policies is the provision of non-material incentives to its employees. According to Priansa (2014), non-material incentives are awards in various forms such as awarding titles, awarding certificates, giving promotions, and so on. This incentives system can be applied to almost all types of jobs, ranging from labor to professional, managerial, and executive employees.

\section{LITERATURE REVIEW}

Job Satisfaction. With the diverse needs of each individual, then job satisfaction can be one of the reasons for every worker to work at a company, so that if all their needs are met then they will feel comfortable at work. Job satisfaction is a reflection in a sense of comfort and secure for the employees of their work done in an organization or company. It also can be seen if an employee feels satisfied with the work done, then the employee seems to get a positive encouragement to improve their quality of work. Sunyoto (2011) defined job satisfaction is a person's individual nature so that they have different levels of satisfaction according to the systems of values that apply to them. This is caused by differences in each individual, the more aspects of the work in serve accordance with individual desires, the higher the value of satisfaction felt and vice versa. Further, Sutrisno (2014) argued that job satisfaction is a pleasant and unpleasant emotional situation for employees to view their work. Job satisfaction reflects one's feelings about their works and it can be seen in the positive attitude of employees towards their working environment. Thus it can be concluded that job satisfaction is the attitude of employees to express their happiness or not to work in the company their work for. Basically, the personality of each individual is not the same, this inequality is caused by how employees receive what they get from the company, whether in the form of compensation, work environment, opportunities for promotion, and so on. According to Murray in Khan, Nawas, Aleem, and Hamed (2012) stated that "Job satisfaction has direct impact on level of absenteeism, commitment, performance and productivity. Furthermore, job satisfaction improves the retention level of employees and reduces the cost of hiring new employees" (p. 2697). Job satisfaction indicators serve as a benchmark in assessing employee job satisfaction levels to determine the extent of their satisfaction levels. 
Mas'ud (2004) explained that there are several indicators of job satisfaction which include satisfaction with the salary received as the first indicators. Other opinions according to Kaswan (2012) stated that how much financial reward is received and how much it is considered appropriate/ fair compared to the rewards given by other organizations. Individuals feel satisfied because of the payroll system is balanced between the productivity incurred with the benefits received. The second indicator is satisfaction with promotion, which is shown by the attitude of employees happy or unhappy about the company's promotion. Kaswan (2014) states that individuals get promotion opportunities because of their good performance to develop themselves through upgrading, education, and training. All of these things will increase satisfaction in doing the work. The third indicator is satisfaction with colleagues that is, an employee's happy or unhappy attitude to the support provided by his coworkers. Other opinions according to Kaswan (2012) stated how many colleagues are technically and socially skilled in providing support. The work environment is an important factor especially in building multi-directional communication that will create comfort at work. The last indicator is satisfaction with the supervisor, which is the attitude of happy or unhappy of an employee, will be treated by the leader. Further, the ability of supervisors to provide technical assistance and behavioral support are needed by the employees. Individuals will feel satisfied if supervised or cared for in doing every job and then they will feel valued. Thus it can be concluded that job satisfaction consists of four important indicators such as satisfaction with the salary received, satisfaction with the promotion, satisfaction with colleagues, and satisfaction with supervisor.

Non Material Incentives. In the prior years, most of the service business companies had the employees who did not have high level of education. With the very rapid business development of the service companies through technology, can increase employee knowledge in order to make a high contribution as the maximum achievement of an organization. As a matter a fact, the needs for the non-material incentive are different from the material incentive. One of the examples is the need for the working environment is one kind of the non-material incentives. If the working environment can ensure and promote the communications among the employees, it would be a good environment for work.

Incentives are one of the awards associated with work performance. The higher work performance, the higher the incentives provided. Mangkunegara (2004) stated incentives are rewards on the basis of high work performance which is a sense of recognition from the organization of employee work performance and contribution to the organization. Further, 
Rivai (2004) explained incentives can be interpreted as a form of payment that is also associated with performance and gain sharing, as a distribution of benefits to employees due to increased productivity or cost savings. Another brief explanation by Siagian (2003) stated the incentive is that the interests of the worker to enable them to maintain their dignity and status as a respectable human being. In this study we will focus on non material incentives, as described by Hasibuan (2011) that non-material incentives are incentives given to employees in the form of awards or confirmation based on work performance, such as the award of certificates, trophies or medals. Furthermore, according to Sanjaya (2014) non-material incentives are stimulants that cannot be valued in money such as awarding a medal, awarding a charter, awarding a certificate, giving oral or written praise, and giving formal or informal thanksgiving. With various awards from non-material incentives, the company encourages and motivates employee morale, so that employees will continue to improve their work to obtain its own benefit in achieving the goals set. From the explanation that has been stated, it can be concluded that non-material incentives consist of six indicators such as the distribution of official titles, the awarding of service uses, the awarding of certificates, promotion, giving the right to use attributes/ facilities, and giving formal or informal praise of thanks.

Employee Performance. Performance is the level of success of employees in completing their work with quality and quantity in accordance with all the responsibilities charged to the employees. Rivai and Basri (2015) stated employee performance is the result or overall level of success of a person during a certain period in carrying out the task compared with various possibilities, such as the standard work results of targets or predetermined criteria which has been mutually agreed upon. Another explanation expressed by Sulistiyani and Rosidah (2003) a person;s performance is a combination of ability, effort, and opportunity that can be assessed by his work. According to Mathis in Mayangsari (2013) stated that employee performance is what affects how much they contribute to the organization among others, such as work quality as a standard that emphasizes more on the quality of work produced than the work volume. Meanwhile the quantity of work is the standard that is done by comparing the amount of work volume that should be (normal work standard) with actual capabilities. The last standard is the use of time, where the use of years of work which is adjusted with company policy. Therefore, it can be concluded that performance is an employee's ability to contribute to the organization in accordance with the responsibilities given to him. Each employee's performance needs to be measured, evaluated, and improved its performance. According to Murty and Hudiwinarsih (2012) employee performance can be measured 
through several indicators such as output quantity, where the amount produced and expressed in terms such as units, the number of activity cycles completed measured by employee perceptions of the number of activities assigned and their results. The second indicator is the quality of output, which is measured by the employee's perception of the work produced and the perfection of the task employee's skills and abilities. Third indicator is output period, where the level of an activity is completed at the beginning of a predetermined time. The period of time is measured from the employee receiving the task until it is finished being an output. The fourth indicator is attendance at work, where they must arrive on time, follow the break time or a meal time that is determined by a record of overall attendance. The last indicator is cooperative attitude, where employees must be able to work together with the leadership and colleagues so that company goals can be achieved properly. Thus it can be concluded that employee performance consists of five indicators such as output quantity, quality of output, period of time, attendance at work, and cooperative attitude.

\section{METHODS}

This research uses descriptive method design to look at specific phenomena or populations obtained by researchers from individual subjects, organizational or other perspectives and get the conclusions based on research results. This study uses primary data by distributing questionnaires to respondents. Technique sampling used in this study is convenience sampling, which is a sampling does not provide equal opportunities for each element or member of the population to be selected as a sample. This technique sampling can facilitate researchers in collecting samples used in this study. The population and sample in this study were all Fave Hotel employees included in the Finance, HRD, House Keeping, Food \& Beverages, Sales \& Marketing, Front Office, Engineer, and Security Department with a total of 61 employees. However, from 61 employees who answered the questionnaires, there were 30 valid, 12 were invalid, and 19 did not return due to resignation and were dismissed from the company. In testing the hypothesis the variables used are job satisfaction and non material incentives as independent variables and employee performance as dependent variables. 


\section{RESULTS}

Descriptive Statistical Analysis. Job Satisfaction on Employee Performance. Significance Test.

\section{Tabel 1. Coefficient}

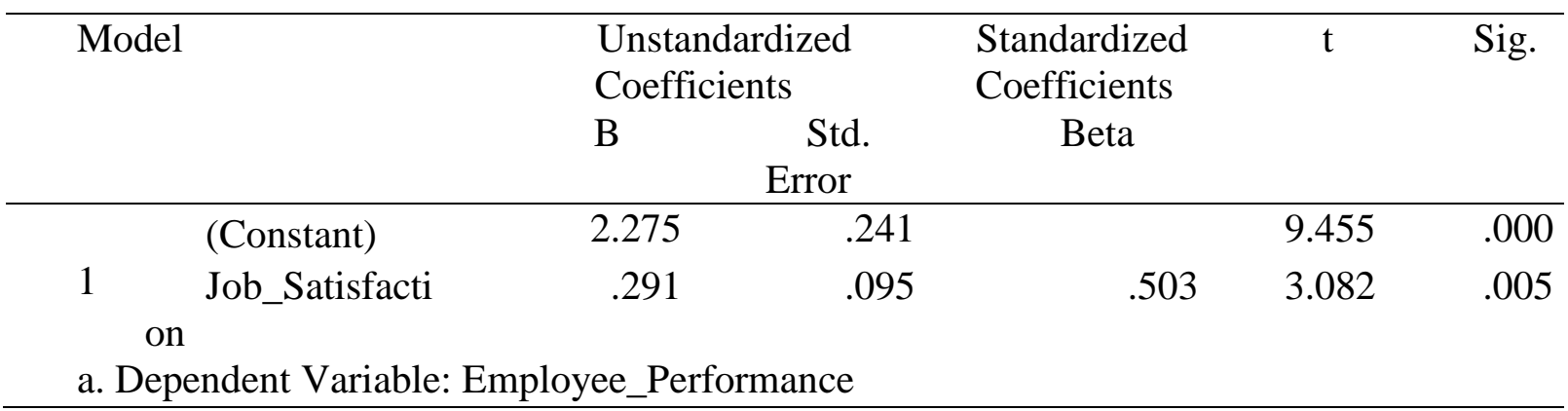

This research uses correlation coefficient to see the strength of the relationship between job satisfaction on employee performance with the value of 0.503 (see Table 1). The results of the correlation coefficient can be interpreted that the relationship between job satisfactions on employee performance is at a moderate level, because every employee assumes that every employee has the opportunity to get a promotion at the company.

Table 2. Partial Test

\begin{tabular}{|c|c|c|c|c|c|c|c|c|c|}
\hline \multirow[b]{2}{*}{$\begin{array}{l}\text { Mode } \\
1\end{array}$} & \multirow[b]{2}{*}{$\mathrm{R}$} & \multirow[b]{2}{*}{$\begin{array}{c}\mathrm{R} \\
\text { Square }\end{array}$} & \multirow[b]{2}{*}{$\begin{array}{l}\text { Adjusted R } \\
\text { Square }\end{array}$} & \multirow{2}{*}{$\begin{array}{l}\text { Std. Error } \\
\text { of the } \\
\text { Estimate }\end{array}$} & \multicolumn{5}{|c|}{ Change Statistics } \\
\hline & & & & & $\begin{array}{l}\text { R Square } \\
\text { Change }\end{array}$ & $\begin{array}{c}\mathrm{F} \\
\text { Change }\end{array}$ & df1 & df2 & $\begin{array}{c}\text { Sig. F } \\
\text { Change }\end{array}$ \\
\hline 1 & .50 & .25 & .227 & .32796 & .253 & 9.5 & & 28 & .005 \\
\hline 1 & $3^{a}$ & 3 & & & & 00 & & & \\
\hline
\end{tabular}

a. Predictors: (Constant), Job_Satisfaction

Testing the effect of job satisfaction variables on employee performance in Table 2 is based on the significance level of $0.005<0.05$. Significance below 0.05 indicates there is a significance influence between variable of job satisfaction on employee performance. Through this result it can be concluded that $\mathrm{Ha}$ is accepted and $\mathrm{H} 0$ is rejected. This indicates that job satisfaction has a significant effect on employee performance. 
Table 3. Non Material Incentive on Employee Performance

\begin{tabular}{cccccccccc}
\hline Model & $\mathrm{R}$ & $\begin{array}{c}\mathrm{R} \\
\text { Square }\end{array}$ & $\begin{array}{c}\text { Adjusted R } \\
\text { Square }\end{array}$ & $\begin{array}{c}\text { Std. Error } \\
\text { of the } \\
\text { Estimate }\end{array}$ & $\begin{array}{c}\text { R Square } \\
\text { Change }\end{array}$ & F Change & df1 & df2 & $\begin{array}{c}\text { Sig. F } \\
\text { Change }\end{array}$ \\
\hline \multirow{2}{*}{1} & .03 & .001 & -.035 & .37936 & .001 & .027 & 1 & 28 & .870 \\
\hline
\end{tabular}

a. Predictors: (Constant), Incentive_Non_Material

This research uses correlation coefficient to see the strength of the relationship between incentive non material on employee performance with the value of 0.031 (see Table 3 ). The results of the correlation coefficient can be interpreted that the relationship between non material incentive and employee performance is at a very low level, because every employee assumes that they are very rare to get an appreciation of non material incentives such as the promotion, award of a charter, and the granting of the right to use an attribute or facility of the organization.

\section{Table 4. Partial Test}

\begin{tabular}{|c|c|c|c|c|c|c|}
\hline \multicolumn{7}{|c|}{ Coefficients $^{\mathrm{a}}$} \\
\hline & \multirow{2}{*}{ Model } & \multicolumn{2}{|c|}{$\begin{array}{c}\text { Unstandardized } \\
\text { Coefficients }\end{array}$} & \multirow{2}{*}{$\begin{array}{c}\text { Standardized } \\
\text { Coefficients } \\
\text { Beta }\end{array}$} & \multirow{2}{*}{$\mathrm{t}$} & \multirow{2}{*}{ Sig. } \\
\hline & & B & Std. Error & & & \\
\hline \multirow{2}{*}{1} & (Constant) & 3.025 & .203 & & $\begin{array}{c}14.9 \\
16\end{array}$ & .000 \\
\hline & $\begin{array}{c}\text { Incentive_Non } \\
\text { Material }\end{array}$ & -.022 & .134 & -.031 & -.165 & .870 \\
\hline
\end{tabular}

a. Dependent Variable: Employee_Performance

Testing the effect of incentive non material variables on employee performance in Table 4 is based on the significance level of $0.870>0.05$. Significance greater than 0.05 indicates there is no significant influence between the variable of incentive non material on employee performance. Through this result it can be concluded that $\mathrm{Ha}$ is rejected and $\mathrm{H} 0$ is accepted. This indicates that incentive non material has no significant effect on employee performance. 
Table 5. Job Satisfaction and Non Material Incentive on Employee Performance

\begin{tabular}{|c|c|c|c|c|c|c|c|c|c|}
\hline \multirow{2}{*}{$\begin{array}{c}\text { M } \\
\text { odel }\end{array}$} & \multirow[t]{2}{*}{$\mathrm{R}$} & \multirow{2}{*}{$\begin{array}{c}\mathrm{R} \\
\text { Square }\end{array}$} & \multirow{2}{*}{$\begin{array}{l}\text { Adjust } \\
\text { ed R } \\
\text { Square }\end{array}$} & Std. & \multicolumn{5}{|c|}{ Change Statistics } \\
\hline & & & & $\begin{array}{l}\text { Error of } \\
\text { the } \\
\text { Estimate }\end{array}$ & $\begin{array}{c}\mathrm{R} \\
\text { Square } \\
\text { Change }\end{array}$ & $\begin{array}{c}\mathrm{F} \\
\text { Change }\end{array}$ & df1 & df2 & $\begin{array}{c}\text { Sig. F } \\
\text { Change }\end{array}$ \\
\hline 1 & $\begin{array}{r}.51 \\
1^{\mathrm{a}}\end{array}$ & $\begin{array}{r}.26 \\
1\end{array}$ & .206 & .33221 & .261 & $\begin{array}{r}4.77 \\
3\end{array}$ & 2 & 27 & .017 \\
\hline
\end{tabular}

a. Predictors: (Constant), Job_Satisfaction, Incentive_Non_Material

This research uses correlation coefficient to see the strength of the simultaneously relationship between job satisfaction and non material incentive on employee performance with the value of 0.511 (see Table 5). The results of the correlation coefficient can be interpreted that the relationship between job satisfaction and incentive non material on employee performance is at moderate level.

Table 6. Simultaneous Test

\begin{tabular}{|c|c|c|c|c|c|}
\hline \multirow[t]{2}{*}{ Model } & \multicolumn{2}{|c|}{$\begin{array}{c}\text { Unstandardized } \\
\text { Coefficients }\end{array}$} & \multirow{2}{*}{$\begin{array}{c}\text { Standardized } \\
\text { Coefficients } \\
\text { Beta }\end{array}$} & \multirow[t]{2}{*}{$\mathrm{t}$} & \multirow[t]{2}{*}{ Sig. } \\
\hline & B & Std. Error & & & \\
\hline (Constant) & 2.351 & .282 & & 8.348 & .000 \\
\hline 1 Incentive Non Material & -.063 & .118 & -.089 & -.537 & .596 \\
\hline Job Satisfaction & .297 & .096 & .513 & 3.084 & .005 \\
\hline
\end{tabular}

a. Dependent Variable: Employee_Performance

Testing the effect of job satisfaction and incentive non material variables on employee performance in Table 6 is based on the significance level of $0.005<0.005$. Significance below 0.05 indicates there is significant influence between the variable of job satisfaction and incentive non material on employee performance. Through this result it can be concluded that $\mathrm{Ha}$ is accepted and $\mathrm{HO}$ is rejected. This indicates that job satisfaction and incentive non material has significant effect on employee performance.

\section{DISCUSSION}

The study aims to determine the effect of job satisfaction and non-material incentives on employee performance. Job satisfaction in this study was measured by the satisfaction with salary received, satisfaction with the promotion, satisfaction with colleagues, and satisfaction with supervisor. Meanwhile, non material incentives was measured by the distribution of 
official titles, awarding of service uses, awarding of certificates, promotion, giving the right to use attributes/facilities, and giving formal or informal praise of thanks. Furthermore, the employee performance was measured by output quantity, quality of output, period of time, attendance at work, and cooperative attitude. The importance of this study is to provide input to the management of the Company that job satisfaction and non-material incentives for the employees is very important and useful to improve employee performance. This study used samples of 30 respondents using multiple linear regressions. The first results of the study explain that there is a significant influence between job satisfaction and employee performance $(\mathrm{r}=0.503, \mathrm{p}<0.005)$. So $\mathrm{H} 0$ was rejected and Ha was accepted. Octaviannand, Pandjaitan and Kuswanto (2017) found that job satisfaction positively affects employee performance. Another literary work by Laosebikan, Odepidan, Adetunji and Aderianto (2018) explains that job satisfaction significantly influences employee performance. Therefore, the results of the present study support the findings of prior studies that connect job satisfaction with employee performance through salary, promotions, colleagues, and superiors who were very supportive with their employees. The second results stated that there is no significant effect between non-material incentives on employee performance $(r=0.031$, p > 0.870). In the literature according to Neckermann and Kosfeld (2008) stated there was a significant effect between non material incentives on employee performance. The theory states the result differently than the statistics, where in the present study, there is no direct positive effect of non material incentive was found on employee performance. This result are corroborated with the respondents' statements where if it is rare to give awards to employees in the form of awards, promotions, giving praise, formal and informal thanks then this will decreased their performance. While the final result of this study has a significant influence between job satisfaction and non material incentives simultaneously on employee performance. This result is in accordance with the respondent's answer that if employees feel satisfied at work and supported by the attention of supervisors in providing awards through non-material incentives, thus they will improve their performance. The implication should be done by the leaders and superiors of the organization or company in order to improve the performance of their employees where is to pay attention through giving non-material incentives, where it looks very small matter but has a very big impact on the achievement of the organization in the future. It can be concluded that the higher performance of employees and the other hand, if the provision of job satisfaction and non material incentive is low, it will lead to decreased employee performance. 


\section{Conclusion}

Based on the results of the data processing and analysis in this study, it can be concluded that respondents regarding the effect of job satisfaction on employee performance produces a correlation coefficient of $r=0.503$, meaning that there is a moderate relationship between job satisfaction and employee performance. Partial significance test ( $t$ test) produce value $0.005<$ 0.05 , then $\mathrm{HO}$ is rejected and $\mathrm{Ha}$ is accepted, which indicates that job satisfaction has a significant effect on employee performance. Then the responses of respondents regarding the effect of non-material incentives on employee performance explain a correlation coefficient of $r=0.031$, meaning that there is a very low relationship between non-material incentives on employee performance. Partial significance test ( $\mathrm{t}$ test) produce value $0.870>0.05$, then $\mathrm{H} 0$ is accepted and $\mathrm{Ha}$ is rejected, which indicates that there is no significance effect between non-material incentives on employee performance. The result of a simultaneous relationship between job satisfaction and non-material incentive on employee performance produces a correlation coefficient of $r=0.511$, meaning there is a moderate relationship between job satisfaction and non-material incentive on employee performance. Simultaneous significance test (f test) produce value $0.017<0.05$, then Ho is rejected and $\mathrm{Ha}$ is accepted, which indicates that there is a significance effect between job satisfaction and non-material incentives on employee performance.

\section{Recommendation}

For further research, the researchers can add other independent variables with factors that affect employee performance from other aspects, add with intervening variables, and also respondents from other industries.

\section{REFERENCES}

Hasibuan, S.P.M. (2011). Manajemen sumber daya manusia. Jakarta: Bumu Aksara

Kaswan. (2012). Manajemen sumber daya manusia untuk keunggulan bersaing organisasi. Yogyakarta: Graha Ilmu

Khan, A.H., Nawaz, M.M., Aleem, M., \& Hamed, W. (2012). Impact of job satisfaction on employee performance: An empirical study of autonomous medical institutions of Pakistan. African journal of business management, 6(7): 2697-2705.

Laosebikan, J.O., Odepidan, M.A., Adetunji, A.V., \& Aderinto, C.O. (2018). Impact of job satisfaction on On employee performance in selected microfinance Banks in Osogbo Metropolis, Osun state, Nigeria, 4(8) 22-46. 
Mangkunegara, A.A.A.P. (2004). Manajemen sumber daya manusia perusahaan. Bandung: PT. Remaja Rosdakarya.

Mas’ud, F. (2004). Survei diagnosis organisasional: Konsep dan aplikasi. Semarang: Badan Penerbit.

Mayangsari, L. (2013). Pengaruh pemberian insentif terhadap kinerja karyawan di departemen penjualan PT. PUSRI. Palembang: Universitas Sriwijaya.

Murty, W.A. \& Hudiwinarsih, G. (2012). Pengaruh kompensasi, motivasi, dan komitmen organisasi terhadap kinerja karyawan bagian akuntansi (Studi kasus pada perusahaan manufaktur di Surabaya). Jurnal The Indonesia accounting review, 2(2), 215-228.

Nasution, M.N. (2015). Manajemen mutu terpadu (total quality management). Edisi Ketiga. Bogor: Ghalia Indonesia

Neckermann, S., \& Kosfeld, M. (2008). Working for nothing? The effect of non-material awards on employee performace.

Octaviannand, R., Pandjaitan, N.K., \& Kuswanto, S. (2017). Effect of job satisfaction and motivation towards employee's performance in XYZ Shipping Company. Journal of education and practice. 8(8), 72-79.

Priansa, D.J. (2014). Perencanaan dan Pengembangan SDM. Bandung: Alfabeta

Rivai, V. (2004). Manajemen sumber daya manusia. Jakarta: PT. Raja Grafindo Persada.

Rivai, V., \& Basri. (2015). Performance appraisal: sistem yang tepat untuk menilai kinerja karyawan dan meningkatkan daya saing perusahaan. Jakarta: PT. Raja Grafindo Persada.

Sanjaya, F.W. (2014). Hubungan pemberian insentif non material terhadap pimpinan dengan semangat kerja pegawai pada dinas pendidikan kota solok. Jurnal administrasi pendidikan. 2(1), 240-831.

Siagian, S.P. (2003). Manajemen sumber daya manusia. Jakarta; Bumi aksara

Sunyoto, D. (2011). Manajemen sumber daya manusia. Jakarta: Center for Academic Publishing Services

Sutrisno, H.E. (2014). Manajemen sumber daya manusia. Cetakan Keenam, Jakarta: Kencana Prenada Media Group

Taurisa, C.M., \& Ratnawati. (2012). Analisis pengaruh budaya organisasi dan kepuasan kerja terhadap komitmen organisasi dalam meningkatkan kinerja karyawan (Studi pada PT. Muncul Kaligawe Semarang). Jurnal bisnis dan ekonomi 19(2), 170-187. Universitas Diponegoro. 